The Mexico Reader 


\section{THE LATIN AMERICA READERS}

A Series Edited by Robin Kirk and Orin Starn

Also in this series:

THE PERU READER: HISTORY, CULTURE, POLITICS

Orin Starn, Carlos Iván Degregori, and Robin Kirk, editors

THE BRAZIL READER: HISTORY, CULTURE, POLITICS

Robert M. Levine and John J. Crocitti, editors

THE ARGENTINA READER: HISTORY, CULTURE, POLITICS

Gabriela Nouzeilles and Graciela Montaldo, editors 

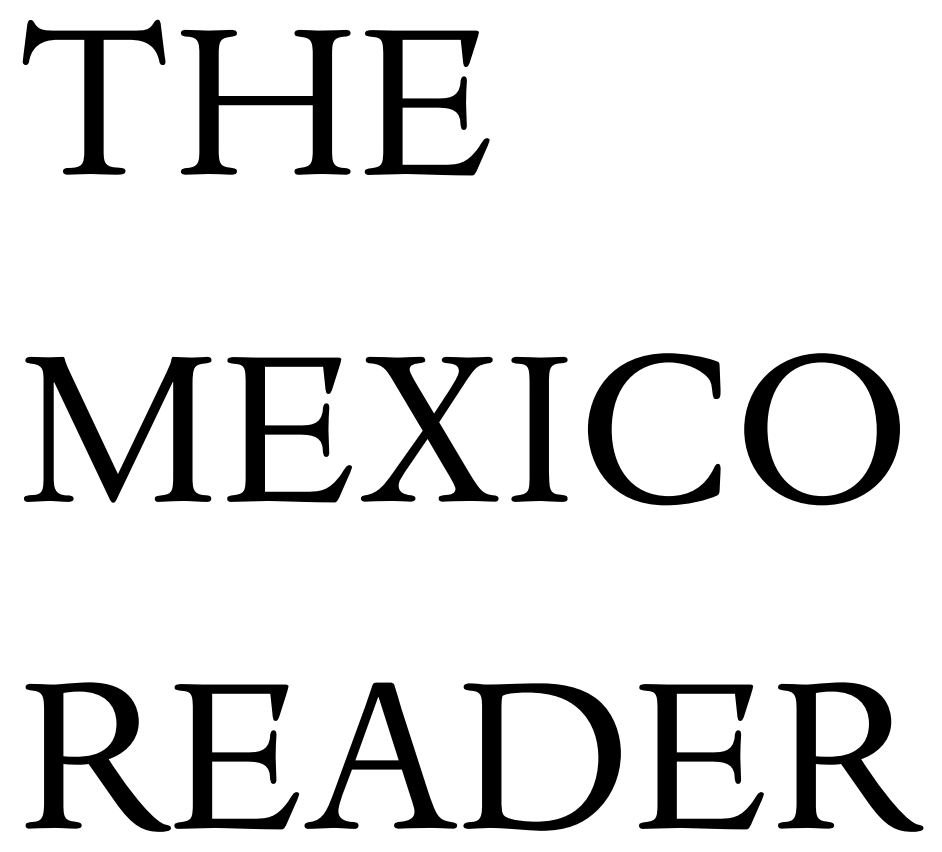

\section{History, Culture, Politics}

Edited by Gilbert M. Joseph and Timothy J. Henderson 
(C) 2002 Duke University Press All rights reserved

Printed in the United States of America on acid-free paper $@$

Designed by Rebecca M. Giménez Typeset in Monotype Dante by Tseng Information Systems Library of Congress Catalogingin-Publication Data appear on the last printed page of this book. Publication of this book has been made possible with the assistance of the Frederick W. Hilles Publication Fund of Yale University. Acknowledgment of copyright begins on page 763 . 
Dedicated to the memory of Pat Bradley,

colleague and friend 
